\section{Lærerikt og tankevekkende om hysteriens historie}

Bondevik $\mathrm{H}$.

Hysteri i Norge

Et sykdomsportrett. 407 s, ill.

Oslo: Unipub, 2009. Pris NOK 379

ISBN 978-82-7477-329-5

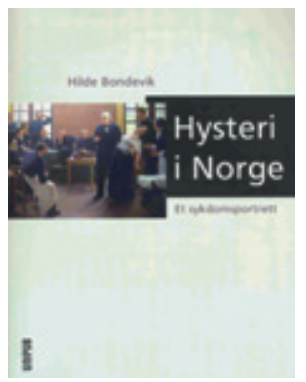

Boken er en bearbeidet utgave av forfatterens doktorgradsavhandling fra 2007, Medisinens orden og hysteriets uorden. Hysteri som er en av medisinens eldste diagnoser og mest

kontroversielle sykdommer, finnes ikke lenger som egen diagnostisk kategori. Men, ifølge forfatteren, eksisterer den kanskje likevel i form av andre uspesifikke sykdomsbetegnelser som somatiseringslidelse, konversjonsnevrose, $\mathrm{AD} / \mathrm{HD}$, dissosiativ lidelse, histrionisk personlighetsforstyrrelse, kronisk tretthetssyndrom, fibromyalgi eller bare psykosomatiske symptomer.

Hysteri er en kulturdiagnose som må konstrueres på tvers av historiske, faglige og kulturelle skillelinjer. Ikke uten grunn hadde hysteri sin gullalder omkring det forrige århundreskiftet, og forfatteren har tatt for seg hysteridiagnosens historie i perioden fra 1870-1915. Hun beskriver fenomenet innen tre ulike undersøkelsesfelt: fagmedisinen, institusjonen/asylet og skjønnlitteraturen.

Innen medisinen blir hysteriet en prøvestein for ulike forklaringsmodeller. På tross av medisinens tradisjonelle analytiske og vitenskapelige tilnærming, kom man ikke frem til noen entydig og konsistent oppfatning av hysteriets vesen eller etiologi. Ideologisk og kulturelt innhold kom stadig til syne i diskusjonen, tydeligst i utfordringen fra kvinnesaken. Hysteriet var først og fremst forbundet med å være kvinne. Hva er kvinnens egentlige natur, og hva er avvik, galskap?

Beskrivelsen av institusjonen er i alt vesentlig hentet fra journalmateriale fra Gaustad sykehus fra 1885 til den første verdenskrig, i alt 1003 journaler. Ikke alle var tilgjengelig. Hysteri ble ofte koblet opp med hypokondri, og selv om storparten av pasientene var kvinner, fikk også en del menn diagnosen. Journalmaterialet viser hvordan situasjonsdiagnosen hele tiden farges av sosiale og kulturelle oppfatninger.

I avsnittet om skjønnlitteraturen beskriver Bondevik en rekke forfattere: Amalie Skram, Bjørnstjerne Bjørnsom og ikke minst Henrik Ibsen med Et dukkehjem, som kanskje det tydeligste eksempelet. Både Helmer, fru Linde og dr. Rank betegner Nora som gal når hun overskrider grensene for kvinnelig atferd.

I den hippokratiske ed inngår at vi som leger ikke skal skade pasienten. Men vi grøsser når vi leser om hvilke behandlinger våre ærede kolleger har gitt sine pasienter i aller beste mening, ut fra sin oppfatning om hva som er avvik og sykdom. Og spørsmålet trenger seg på: Hvilke forferdeligheter er det $v i$ utfører i dag i aller beste mening?

Idéhistorikere, som Hilde Bondevik, kan hjelpe oss til å se og undre oss, kanskje også til å revurdere noe av vår praksis i tide.

\section{Astrid Nøklebye Heiberg}

Institutt for psykiatr

Universitetet i Oslo

\section{Psykiatrisk forskning og kunnskapsgrunnlag}

Jørgensen $P$, Nordentoft M, Videbech P. Håndbog i psykiatrisk forskning \& evidens 187 s, ill. København: FADL's forlag, 2009 Pris DKK 269

ISBN 978-87-7749-700-1

Forfatterne skriver at boken har som formål «at medvirke til, at psykiatrisk forskning bliver både selvfølgelig og overkommelig $i$ en travl klinisk hverdag og at give let tilgjængeligt overblik over den eksisterende kliniske evidens for behandling av patienter.»

I fire deler omtales følgende:

- Psykiatriens vitenskapelighet og hvordan den har utviklet seg historisk

- Praktiske problemer som man kan forvente å møte når man gir seg i kast med et forskningsprosjekt innenfor psykiatri

- Resymé av den kliniske effektforskning innen de store psykiatriske lidelser og sykdommer

- Gjengivelse av Helsinki-deklarasjonen om retningslinjer for biomedisinsk forskning og Madrid-deklarasjonen om psykiatriens etiske retningslinjer

Målgruppen er alle innenfor det brede voksenpsykiatriske området, enten de ønsker å starte et forskningsprosjekt eller få en introduksjon til klinisk forskning og det eksisterende kunnskapsgrunnlaget for behandling. Videre er målet at kunnskapssøkende pasienter og aktive pårørende skal «finde stikord til den evidensbaserede behandling.»

Dette er en krevende målsetting. Utfordringen blir ikke mindre av at man har valgt et håndbokformat «for at sikre bogen plads i arbeidstasken, på konferencebordet eller på den lille hylde på kontoret, som kun tillader plads til fă bøger.» En av begrensningene ligger nettopp i formatet. Som forfatterne skri- ver: «Som håndbog er der i valget av sprog og opsætning satset på enkelhed og overskuelighed frem for fuldstændighed og detaljerigdom; disse finder man $\mathrm{i}$ andre bøger, som man etterfølgende kan fordybe seg i.»

Etter min mening lykkes boken med å gi nøktern og vederheftig informasjon. Men for å dekke så mange områder innenfor liten plass har forfatterne måttet være selektive $i$ hva de tar med. Mange lesere vil nok derfor temmelig raskt føle behov for å gå til mer fullstendige kilder. Boken er derfor først og fremst å betrakte som en appetittvekker.

En liten innvending til slutt: Skriften er så liten at den forutsetter at leseren har godt syn.

\section{Svein Friis}

Klinikk psykisk helse og avhengighet Oslo universitetssykehus, Ullevål

\section{Nyttig om sosial kapital}

Rønning R, Starrin B, red. Sosial kapital i et velferdsperspektiv Om å forstå og styrke utsatte gruppers sosiale forankring. 198 s, tab, ill. Oslo: Gyldendal Akademisk, 2009. Pris NOK 295

ISBN 978-82-05-39248-9

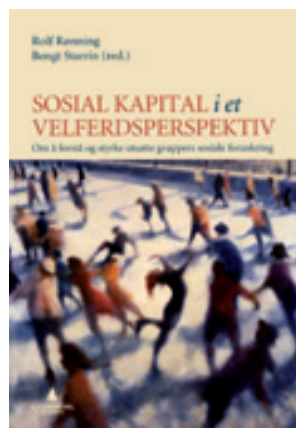

Denne antologien er først og fremst god som lærebok for studenter i helse- og velferdsfag. Men også andre kan ha nytte av denne innføringen $\mathrm{i}$ begreper og teorier om sosial kapital og hvordan disse kan

brukes i all slags sosialt arbeid.

Boken er et resultat av samarbeid mellom Høgskolen på Lillehammer og Universitetet i Karlstad. I alt 14 forfattere skriver om hvordan begrepet sosial kapital kan brukes til å forstå brukere av sosiale velferdstjenester. De diskuterer videre om teorien også kan gi rettledning for tiltak i slikt arbeid.

Sosial kapital kan oppfattes som ganske selvfølgelig, at sosialt nettverk og sosiale fortjenester i lokalmiljøet kan gi noe å falle tilbake på i vanskelige tider. Men teorien gir dertil en rekke begreper som kan være nyttige, f.eks. «bonding» kapital, som bidrar til å knytte en gruppe sammen, versus «bridging» kapital, som gjør det lettere å etablere nye nettverk.

Teorien analyseres både generelt og spesielt i forhold til helse, marginalitet, psykisk utviklingshemning, barnevern, aldersboliger, innvandrere og gründere i ulike lokalsamfunn - typiske grupper som vernepleiere, sykepleiere, sosionomer og trygde- 
funksjonærer jobber blant. Alle disse avsnittene overbeviser om at begrepene er viktige når det gjelder å forstå mange brukere og deres livssituasjon. Her er også gode eksempler på å forklare hvorfor tiltak ikke fører frem. Et eksempel er mislykket attføring av mennesker som må flytte for å ha sjanse til en jobb, men som ikke kan risikere å gi opp det sosiale nettverket de strever for å ha på hjemstedet.

Derimot er det vanskelig å finne gode eksempler på at teorien om sosial kapital kan brukes til å formulere gode tiltak i velferdsarbeid. I vårt land er mye allerede gjort, f.eks. å organisere eldresentre, boenheter for psykisk utviklingshemmede og mye annet. Nye forslag er ikke lett å komme med. Men de bør komme, f.eks. i skolene og i barnevernet. Således er denne boken svært velkommen.

\section{Bjørgulf Claussen}

Institutt for helse og samfunn

Universitetet i Oslo

\section{Dansk seniorpolitikk - apokalypse nå!}

Ishøy T, red.

\section{Alle disse løfter om et tidssvarende} sundhedsvæsen

En debatbog om de danske sygehuse. 285 s, tab, ill. København: Forlaget Vandkunsten, 2010. Pris DKK 229

ISBN 978-87-7695-156-6

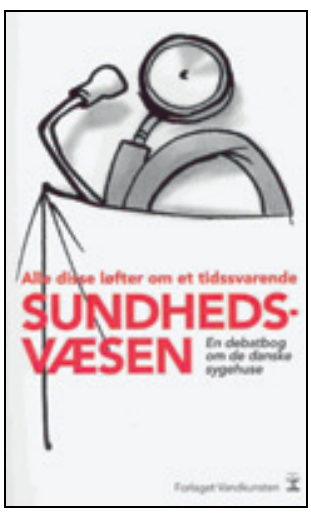

Da jeg leste denne boken, var det raskt to danske organisasjoner jeg måtte google. Den ene var Dansk Selskab til Sikring af Lægers Ytringsfrihed (DSLY; $h t t p: / / d s l y . d k /)$. I deres formålsparagraf står det bl.a: «Selskabets formå er at sikre lægers ytringsfrihed i overensstemmelse med gældende love, vedtægter og internationale deklarationer til gavn for patienterne og sundhedsvæsenet. Samtidig vil selskabet støtte medlemmer, der kommer i knibe i forhold til ytringsfriheden og søge at forhindre, at dette sker i fremtiden (...).»

Den andre organisasjonen, som i boken fremstår som den store stygge ulven, heter DJØF. Det er tydelig at bokens redaktør, Torben Ishøy, tar det som en selvfølge at alle lesere vet hva disse bokstavene står for, men det visste altså ikke jeg. DJØF er forkortelsen for Danmarks jurist- og økonomforbund, og på hjemmesiden (www.djoef.dk/) heter det: «DJØFs over 69.000 medlemmer arbejder bl.a. med jura, økonomi, administration, forvaltning, forskning, undervisning, kommunikation og ledelse.»

Når jeg nevner dette, er det fordi jeg lurer på om en bok som denne i det hele tatt ville kunne bli utgitt i Norge. Her har vi ingen egen organisasjon (utenfor Legeforeningen) til å ivareta legenes ytringsfrihet, men opplever heller ikke en så massiv og konkret legefiende som DJØF tydeligvis er.

Hva handler så denne boken om? Den presenteres som en debattbok om de danske sykehusene. Det kan man trygt si at den er, bortsett fra at det ikke foregår noen debatt i selve boken. Den representerer en samstemt og kraftig bredside mot danske samfunnsinstitusjoner, og i særdeleshet helsevesenet og måten sykehusene drives på. 15 av de 16 bidragsyterne er mannlige nåværende og pensjonerte overleger og professorer, den siste er kvinnelig sykepleier med samme etternavn som en av overlegene. Gjennomsnittsalderen for de debatterende legene er 69 år, med et spenn fra 53 år til 91 år.

Dette bør selvsagt ikke nødvendigvis svekke sakligheten. Pensjonerte leger kan komme med offentlig kritikk av systemet uten å risikere å miste jobben, en risiko som også finnes her til lands (1). Dessuten er det ikke utenkelig at en eldre erfaren overlege kan komme med nyttige og konstruktive forslag til endringer og forbedringer av systemene.

Dessverre er det ikke konstruktive forslag som preger denne boken. Den fremstår, med noen få hederlige unntak, som en endeløs klagesang, stort sett over temaet «alt var mye bedre før». Flere av innleggene bekrefter alle forestillinger om eldre mannlige overleger som arrogante besserwissere, og både sykepleiere og pasienter får sine pass skikkelig påskrevet. Men hovedfienden er de før omtalte DJØF-erne. Vi kjenner denne type beskrivelser fra norske humorister, for eksempel i en artikkel om kunsten å svømme blant haier (2), bare at her er det blitt blodig alvor. Som redaktøren Torben Ishøy skriver i sin lange og nokså snirklete klagesang: «Bureaukrater og hofsnoge har inndtaget væsentlige kontrollposter, som den syge intetanende må passere for at kunde gennemføre den lange vandring opad gennem systemet.»

Et innlegg som skiller seg positivt ut er Lars Heslets «Fremtidens hospital». Han har bl.a. skrevet boken Sansernes hospital (3), og jeg antar hans kapittel er en kortversjon av denne. Han viser på en overbevisende måte hvordan sykehusbyggene, særlig der hvor man må forholde seg til gamle bygninger beregnet på gårsdagens behandlingsregimer, ikke har maktet å følge med i den kunnskapsbaserte teknologiutviklingen, for eksempel ved å fjerne unødvendige stresselementer for personalet og pasienter. Det handler bl.a. om så enkle ting som å redusere støy og sørge for optimale lysforhold.

Det internasjonale perspektivet er totalt fraværende. Den danske nedturen som beskrives blir ikke satt i relieff til andre lands «nedturer». For meg blir dette en samling apokalyptiske skrifter fra en avgående legegenerasjon som er frustrert fordi de ikke selv lenger sitter ved roret. Hvorfor gjorde de ikke mer da de var yngre og saftigere?

\section{Olaf Gjerløw Aasland}

Legeforeningens forskningsinstitutt

\section{Litteratur \\ Aasland OG, Førde R. Legers faglige ytringsfrihet. Tidsskr Nor Legeforen 2008; 128: 1838-40. \\ 2. Iversen $\mathrm{OH}$. Kunsten å svømme blant hai. Tidsskr Nor Lægeforen 2003: 123: 1157-8. \\ . Heslet L. Sansernes hospital. København: Arkitek- tens forlag, 2007}

\section{Nyttig om inflammasjon i mage-tarm-kanalen}

Mayerle J, Tilg H, red.

Clinical update on inflammatory disorders

of the gastrointestinal tract

216 s, tab, ill. Basel: Karger, 2009. Pris CHF 182

ISBN: 978-3-8055-9294-9

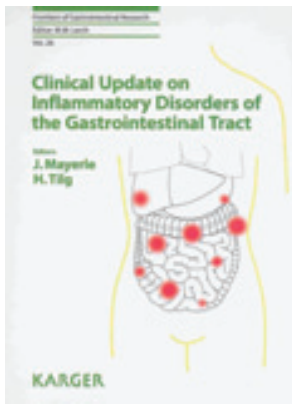

Dette er bind nr. 26 i serien Frontiers of gastrointestinal research og omhandler ulike aspekter ved inflammasjon i mage-tarmkanalen. Det er en ambisiøs oppgave å dekke et så vidtspennende tema

i en bok på ca. 200 sider, men som tittelen antyder, er intensjonen å gi en oppdatering innen feltet, ikke å være en lærebok.

I fire deler (hepatologi, gastroenterologi, pancreassykdommer og ventrikkelsykdommer) presenteres kapitler som i realiteten er isolerte oversiktsartikler av ulike forfattere. De fleste kapitlene omhandler spesifikke temaer, et fåtall omtaler inflammasjon generelt. Fokus varierer fra basalfag til praktiske kliniske problemstillinger, men også nye og mulig fremtidige behandlingsmetoder omtales. Temaene spenner eksempelvis fra immunterapi ved pancreascancer via probiotika ved ulike sykdommer i mage-tarm-kanalen til eradikasjon av Helicobacter pylori. Det virker noe tilfeldig hvilke temaer som er omtalt, og fremstillingen er fragmentert og ufullstendig. På den annen side er majoriteten av kapitlene godt skrevet, gir oversiktlig presentasjon av de enkelte temaene og har gode illustrasjoner. 